\title{
The Influence of Spiritual Intelligence and Emotional Intelligence 0n Job Satisfaction and Nursing Performance
}

\section{Komang Trisna Sari Dewi*}

Sekolah Tinggi Ilmu Ekonomi Satya Dharma

\section{A R T I C L E IN F O}

Article history:

Received 01 December 2019

Received in revised form

31 December 2019

Accepted 15 January 2020

Available online 26

February 2020

Keywords:

Emotional Intelligence,

Spiritual, Job Satisfaction,

Performance

\begin{abstract}
A B S T R A C. T
Hospital is one of the public service places engaged in the field of health services where there is a lot of interaction between nurses and patients. Nurses are required to have the ability to manage emotional intelligence and spiritual intelligence possessed. The purpose of this study was to determine the influence of emotional intelligence and spiritual intelligence on job satisfaction and nurse performance at Buleleng General Hospital. The samples of this study were 76 respondents selected by using probability sampling techniques. The data analysis technique used in this study was a structural equation model based on variance and component based SEM with smartPLS 3.0 analysis tools. Based on the result of hypothesis testing shows that emotional intelligence has a significant positive effect on job satisfaction. Second, emotional intelligence has a significant positive effect on nurse performance. Third, spiritual intelligence has a significant positive effect on job satisfaction. Fourth, spiritual intelligence has a significant positive effect on nurse performance
\end{abstract}

\footnotetext{
* Corresponding author.

E-mail addresses: komangtrisnasaridewi@yahoo.com (Komang Trisna Sari Dewi)
} 


\section{Introduction}

Hospital as one of the public service institutions are required to be able to provide good services for users of the service. So that human resources are needed that can provide good public services. As part of the public service providers, hospitals are required to be able to provide quality services, fast, easy, affordable and measurable to the community and related parties. Gillies (2000) states that one of the very important efforts in improving the quality of nursing services is to improve human resources and management of nursing management. Most human resources who interact directly with patients are nurses, so the quality of services carried out by nurses can be assessed as one indicator of good or poor quality of service in hospitals (Aditama, 2007). Clients in the Hospital are provided services by a team of nurses in accordance with professional beliefs and established standards. It is intended that the services provided to clients can meet client expectations. On the other hand, the nurse is expected to play a role in the ward, be ready at any time when needed, be responsive to complaints, and take part in what the client is going through. The clients want the nurse who serves them to have a good attitude, smile, be patient, and be able to speak language that is easily understood, and wishes to help the sincere and able to respect the client and their opinion. The client expects the nurse to have adequate knowledge about the condition of the illness so that the nurse is able to deal with every complaint experienced by the individual client. However, there are still many complaints from clients about nurses who are less friendly, less responsive, and less competent.

Different character of clients is challenge for nurses in dealing with clients. The existence of emotional intelligence and spiritual intelligence possessed by nurses will affect the way nurses deal with clients. Emotional intelligence is giving an awareness of one's own feelings and the feelings of others. Emotional intelligence means giving empathy, love, motivation, and the ability to respond to sadness and joy appropriately. Goleman (2000) defines emotional intelligence as the capacity to recognize feelings of oneself and others, in motivating oneself and managing emotions with both in ourselves and in our relationships. Goleman explained that mood coordination is the essence of good social relations. If a person is good at adjusting to the mood of other individuals or can empathize, that person will have a good emotional level and will be easier to adjust in social relationships and the environment. Goleman also stated that emotional intelligence is more ability possessed by a person in motivating themselves, resilience in the face of failure, controlling emotions and delaying gratification, and regulating the soul. By emotional intelligence, a person can place his emotions in the right portion, have satisfaction and set the mood. Agustian (2006), translating emotional intelligence is the ability to feel. The key to emotional intelligence is the honesty of conscience. It is the voice of the heart that should be the center of principles that are able to provide security, guidance, strength and wisdom.

Good emotional intelligence is needed by a nurse. Work as a nurse requires expertise and skills to meet the needs of patients that include biological, psychological, sociological, and spiritual needs. So to be able to provide good service requires the ability to manage emotions properly that will improve the quality of nursing services in order to encourage increased social behavior and performance of nurses to patients. Also in working emotional intelligence is closely related to job satisfaction. disrupted emotional intelligence will cause a person unable to achieve maximum job satisfaction. Job satisfaction reflects a person's attitude towards his work. It appears in the employee's positive attitude towards work and everything that is encountered in his work environment. Employees with low emotional intelligence tend to experience emotional tension and avoid problematic situations that cause pressure on him which results in not overcoming problems so disrupt the employee's own performance. As a result employees do not have self-control so that employees view the work as a burden. This of course makes employees have negative feelings about their work and result in low employee job satisfaction. In addition to emotional intelligence, spiritual intelligence possessed by a nurse will help direct him to live a role in helping patients, not only as a form of health service but also as a form of worship to interpret life before God. Spiritual intelligence is the intelligence to face and solve problems of meaning and value that is broader and richer, the intelligence to judge that one's actions or way of life are more meaningful than others (Zohar and Marshall, 2007: 4). Khavari (2006: 28) says that spiritual intelligence is the intelligence of the human soul. Spiritual intelligence is the hidden potential possessed by everyone. Spiritual intelligence gives us eyes to see the positive value in every problem and the wisdom to deal with problems and take advantage of them. Spiritual intelligence is the ability to respond to and treat others as you and the motivation that underlies every action is done not solely for one's own sake but is more concerned with the interests of many people on the basis of equality as fellow creatures of God's creation. Spiritual intelligence makes humans rightintact intellectually, emotionally and spiritually. Spiritual intelligence issoul intelligence.Nurses who have high spiritual intelligence are able to becomehappier and live life than those who are intelligentspiritual low. Spiritual intelligence is able to lead humans tofind meaning in very 
bad and unexpected conditions.The search for meaning for nurses should be able to link givingnursing services on the basis of worship to God and help for humans who need.

Quality human resources are expected to be able to have a major influence on the sustainability of the company. So the emotional and spiritual intelligence possessed by human resources will affect the performance and job satisfaction of the human resources themselves. Like the results of research conducted by Sukmawati (2014) shows that there is a positive influence of emotional intelligence on employed job satisfaction. Conducted by Sunandar (2016) show that there is an influence of spiritual intelligence on job satisfaction. His research shows that the level of intelligence increases spiritual, then job satisfaction will be more increasing. The results of research conducted by Handayani (2014) states that there is an influence of emotional intelligence and spiritual intelligence on employee performance. Research conducted shows that the ability to use emotional intelligence effectively in managing one's own feelings and in positive relationships with others is good. This is in line with research conducted by Edwardin (2006) which says that emotional intelligence and spiritual intelligence have a positive influence on employee performance. But there are some other opinions that say that emotional and spiritual intelligence has no effect on performance. One of them is Gordon who said that the best way to improve employee performance is with analytical skills and cognitive abilities in this case whose role is intellectual intelligence.

Based on the explanation above, the writer interested in conducting research by conducting studies on emotional intelligence and spiritual intelligence, with the research problems as follows: (1) Can emotional intelligence increase nurse job satisfaction? (2) Can emotional intelligence improve nurse performance? (3) Can spiritual intelligence increase nurse job satisfaction? (4) Can spiritual intelligence improve nurse performance? Based on the description about the variables studied, the theoretical framework can be formulated as follows:

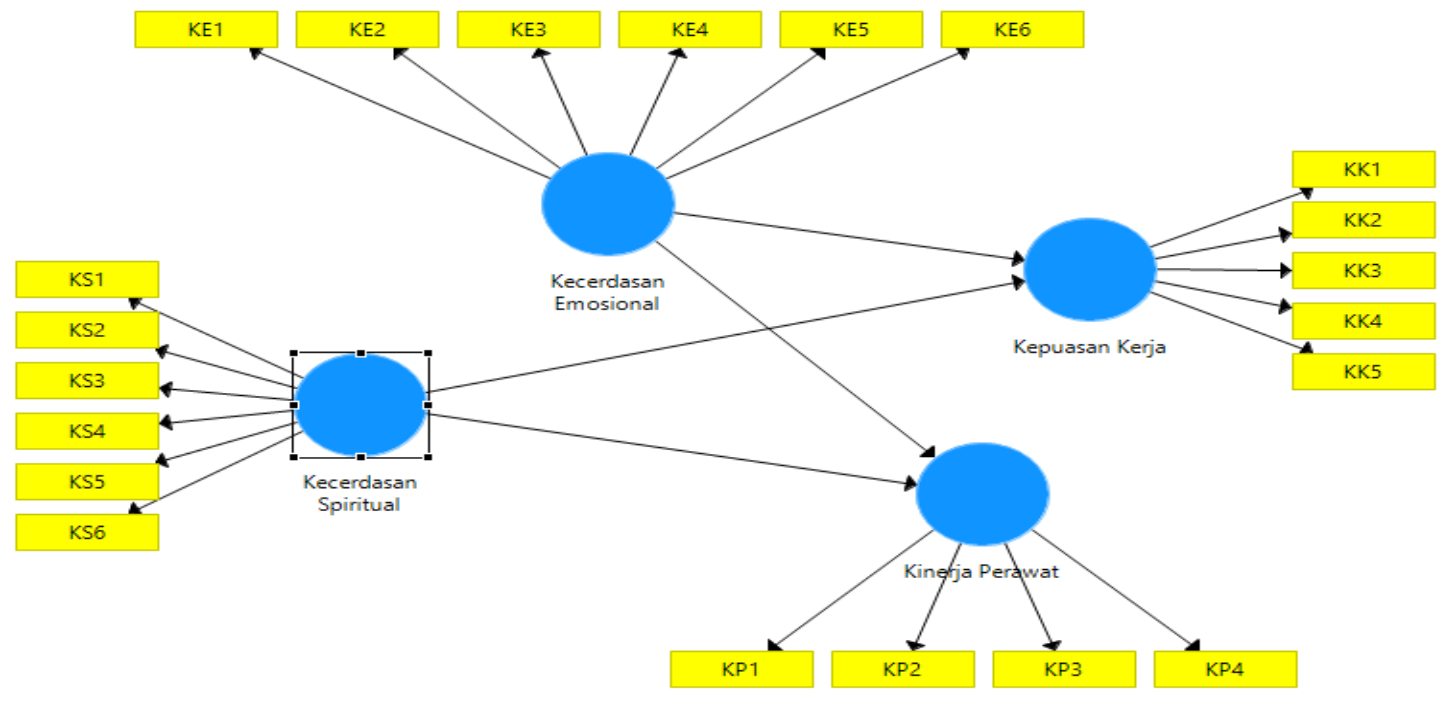

Figure 1. Theoretical Framework

\section{Methods}

This research conducted at the Buleleng General Hospital, located on Ngurah Rai Street No. 30, Astina. The populations in this study were all nurses in Buleleng General Hospital. The sampling technique in this study used probability sampling, where all elements of the population have the same opportunity to be sampled. Probability sampling used simple random sampling, which was a random sampling without regard to strata in the population. Selection of samples with the right method can accurately describe the actual population conditions, and can save research effectively. So that in this study, the researcher used Sloven formula to determine the sample 322 nurses. The fault tolerance limit that researchers use is $10 \%$ with an accuracy level of $90 \%$. Based on the results of calculations by using Slovin formula, sample of 76 is obtained. The research instrument used as a data collection tool was a questionnaire. From 76 questionnaires that have been distributed, obtained that all questionnaires have been returned and filled out completely. The data that has been collected is then analyzed with analysis techniques in the form of 
structural equation models (Structural Equation Modeling-SEM) based on variance or Component based SEM, which is well known as Partial Least Square (PLS) Visual version 3.0.

\section{Result And Discussion}

In this study there are four constructs consisting of two hexogen variables and two endogenous variables. The first hexogen variable is emotional intelligence measured by six indicators namely KE1, KE2, KE3, KE4. KE5 and KE4. The second hexogen variable is spiritual intelligence measured by 6 indicators, namely KS1, KS2, KS3, KS4, KS5, and KS6. While the first endogenous variable is job satisfaction measured by five indicators namely KK1, KK2, KK3, KK4, and KK5. The second endogenous variable is nurse performance measured by four indicators, namely KP1, KP2, KP3, and KP4.

The construct is said to have high reliability if the Composite Reliability value is above 0.70 and the Cronbach Alpha value is above 0.60 (Ghozali, 2008). Table 1 presents the Composite Reliability and Cronbach Alpha values for all variables.

Table 1. COMPOSITE RELIABILITY AND CRONBACH'S ALPHA VALUE

\begin{tabular}{lll}
\hline & Cronbach's Alpha & Composite Reliability \\
\hline Emotional Intelligence & 0.906 & 0.928 \\
Spiritual Intelligence & 0.882 & 0.909 \\
Job satisfaction & 0.870 & 0.906 \\
Nurse Performance & 0.815 & 0.878 \\
\hline
\end{tabular}

Source: Processed Data

In table 1 above, it shows that the Composite Reliability value of all variables above 0.70 with the lowest value of 0.878 on the construct of the nurse's performance and value. Cronbach's Alpha is above 0.60 with the lowest value of 0.815 in the construct of nurses' performance. So it can be concluded that the construct in research is reliable.

The researcher also uses the Average Variance Extracted (AVE) method to strengthen the valid statements in this study. Average Variance Extract (AVE) is said to be good if it has a value above 0.50 (Ghozali, 2008). Table 2 presents the results of the Average Variance Extracted (AVE) test.

Table 2. AVERAGE VARIANCE EXTRACTED VALUE (AVE)

\begin{tabular}{ll}
\hline & Average Variance Extracted (AVE) \\
\hline Emotional Intelligence & 0.681 \\
Spiritual Intelligence & 0.626 \\
Job satisfaction & 0.660 \\
Nurse Performance & 0.643 \\
\hline
\end{tabular}

Source: Processed Data

Table 2 above shows the AVE value for all constructs above 0.50 with the lowest AVE value found in the spiritual intelligence construct that is 0.626 . So it can be concluded that the construct in this study is valid.

Structural Model Testing (Inner Model)

In assessing the model with PLS, it starts by looking at the R-square for each latent dependent variable (Ghozali, 2008). Table 3 is the result of R-square estimation using SmartPLS.

Table 3. R SQUARE VALUE

\begin{tabular}{lll}
\hline & R Square & R Square Adjusted \\
\hline Job satisfaction & 0.687 & 0.678 \\
Nurse Performance & 0.639 & 0.629 \\
\hline
\end{tabular}

Source: Processed Data

Based on the determination coefficient data above, it is known that the R-Square value of the construct of Job Satisfaction is 0.687 , equal to $68.7 \%$ of the job satisfaction construct can be explained by the variable construct of emotional intelligence and spiritual intelligence. While the R-Square value of the 
construct of nurse performance is equal to 0.639 equal to $63.9 \%$ construct of nurse performance can be explained by the construct variables of emotional intelligence and spiritual intelligence.

The significance of the endogenous indicators can be seen from the T-statistic value. If $t$-value $\mathrm{t}$ Table, all indicators can be said to be significant in measuring endogenous constructs. The results of testing with the bootstrapping method of SEM PLS analysis are shown in Figure 2.

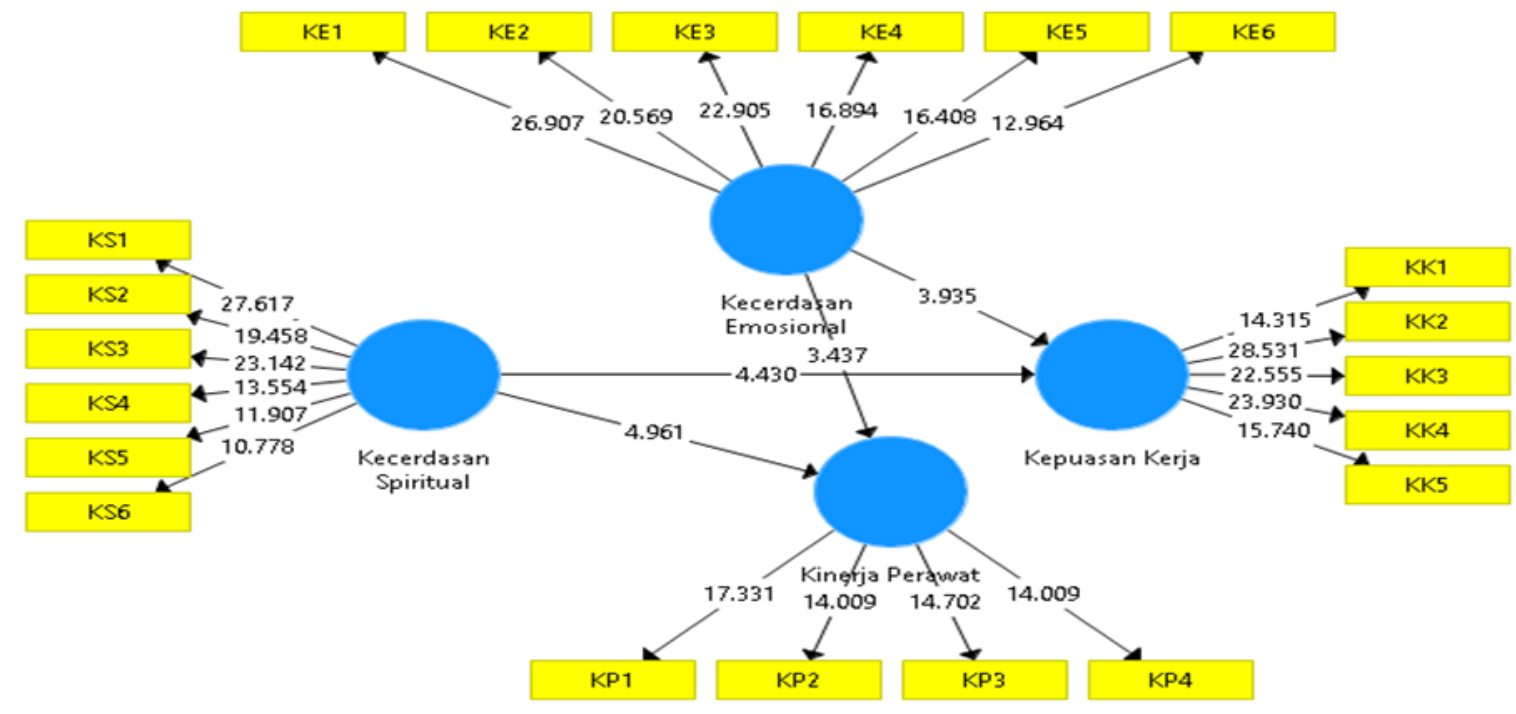

Figure 2. Testing with the bootstrapping method of SEM PLS

The basis used in testing hypotheses is the value contained in the output result for inner weight. Table 4 provides estimated outputs for testing structural models.

Table 4. RESULT FOR INNER WEIGHT

\begin{tabular}{lccccc}
\hline & $\begin{array}{c}\text { Original } \\
\text { Sample (0) }\end{array}$ & $\begin{array}{c}\text { Sample } \\
\text { Mean } \\
(\mathrm{M})\end{array}$ & $\begin{array}{c}\text { Standard } \\
\text { Deviation } \\
(\text { STDEV })\end{array}$ & $\begin{array}{c}\text { T Statistics } \\
(\mid \text { OSTDEV|) }\end{array}$ & P Values \\
\hline $\begin{array}{l}\text { Emotional Intelligence -> Job } \\
\text { Satisfaction }\end{array}$ & 0.408 & 0.406 & 0.104 & 3.935 & 0.000 \\
\hline $\begin{array}{l}\text { Emotional Intelligence -> Nurse } \\
\text { Performance }\end{array}$ & 0.376 & 0.370 & 0.110 & 3.437 & 0.001 \\
\hline $\begin{array}{l}\text { Spiritual Intelligence -> Job } \\
\text { Satisfaction }\end{array}$ & 0.478 & 0.485 & 0.108 & 4.430 & 0.000 \\
\hline $\begin{array}{l}\text { Spiritual Intelligence -> Nurse } \\
\text { Performance }\end{array}$ & 0.478 & 0.494 & 0.096 & 4.961 & 0.000 \\
\hline
\end{tabular}

a. The Effects of Emotional Intelligence on Job Satisfaction

The results of testing the first hypothesis shows that the relationship of emotional intelligence with job satisfaction has a parameter coefficient of 0.408 with a t value of 3.935 where the value is greater than $\mathrm{t}$ table (1.906). These results indicate that emotional intelligence has a positive and significant relationship to job satisfaction. Hypothesis 1 is accepted. The higher the emotional intelligence so that also the higher the job satisfaction. The results of this research reinforce research conducted by (Thomas, Sy, et al, 2006), which states that the level of emotional intelligence of employees is positively related to job satisfaction. This research is in line with research conducted (Supriyanto, 2012), which states that emotional intelligence has a significant effect on job satisfaction. With high emotional intelligence possessed by a nurse where he/she is able to control himself so that he/she can respond to every situation faced optimistically and is able to determine the attitude needed if the nurse experiences obstacles in resolving a problem at work. When a person has self-control, he/she will see a challenge at work as a chance for success. With the positive feelings held by a nurse for her work that supports high job satisfaction also in the nurse his/herself. 


\section{b. The Effects of Emotional Intelligence on Nurse Performance}

The second hypothesis testing result shows that the relationship of emotional intelligence with nurse performance has a parameter coefficient of 0.376 with a t value of 3.437 where the value is greater than $t$ table (1.906). These results indicate that emotional intelligence has a positive and significant relationship to nurse performance. Hypothesis 2 is accepted. The higher the emotional intelligence, the higher the nurse's performance. This is in line with research conducted by (Trihandini, 2005), which says that emotional intelligence has a significant positive effect on employee performance. Emotional intelligence (EQ) has an important role in the work environment, because it involves various issues that must be discussed by employees, for example regarding tasks, uncomfortable working atmosphere, and relationship problems with others. The problems that exist in the world of work can not only be solved by intellectual ability, but also in the problems that are needed as well. Nurses as a service-oriented profession require a skill in managing their emotions. Nurses are always dealing with patients who have different backgrounds, ages and characters. It is not easy for a nurse to handle a variety of patients with different characters. So that the emotional intelligence possessed by a nurse can be one of the factors that can improve the performance of nurses in handling their patients. Emotional mastery skills are very influential on performance. Emotional intelligence plays a role in making a meaningful contribution in helping to improve work output. Working days that are passed without applying emotional intelligence can lead to boredom, the ability of a nurse to be able to respect herself and others, understand the deepest feelings of people around her, follow the rules that apply. All of this includes the key to success for a person.

c. The Effects of Spiritual Intelligence on Job Satisfaction

The third hypothesis testing result shows that the relationship of spiritual intelligence with job satisfaction has a parameter coefficient of 0.478 with a $t$ value of 4.430 where the value is greater than $t$ table (1.906). These results indicate that spiritual intelligence has a positive and significant relationship to job satisfaction. Hypothesis 2 is accepted. The higher the spiritual intelligence, the higher the job satisfaction. This is in line with research conducted (Supriyanto, 2018), which states that spiritual intelligence has a significant effect on job satisfaction. Intelligence spiritual has a positive influence and significant on job satisfaction. From this research can be revealed that spiritual intelligence of the executing nurse will affect job satisfaction. The smarter the nurses implement job satisfaction as well

will increase. This is in line with opinion; Hasibuan (2009), level Individual satisfaction varies accordingly

with the value system that applies to himself. The results of this study also support research conducted (Moore, et al, 2006) saying that spiritual intelligence is very influential on job satisfaction. With high spiritual intelligence, a nurse will be able to interpret positively in every event and problem she experiences, so that she is able to carry out positive, positive actions. The more spiritually intelligent, then a nurse will feel satisfied in carrying out their duties and responsibilities as a nurse. When a nurse carries out her work inspired by a pure vision and mission, it will make them feel satisfied in doing any work that has become her commitment.

\section{d. The Effects of Spiritual Intelligence on Nurse Performance}

The fourth hypothesis testing results indicate that the relationship of spiritual intelligence with nurse performance has a parameter coefficient of 0.478 with a t value of 4.961 where the value is greater than $t$ table (1.906). These results indicate that spiritual intelligence has a positive and significant relationship to nurse performance. Hypothesis 4 is accepted. The higher the spiritual intelligence, the higher the nurse's performance. This is in line with research conducted by (Trihandini, 2005), which says that spiritual intelligence has a significant positive effect on employee performance. High spiritual intelligence is characterized by growth and transformation in a person, achieving a balanced life between career / work and personal / family, as well as feelings of joy and satisfaction that are manifested in the form of generating positive contributions and sharing happiness to the environment. Spiritual intelligence allows a person to think creatively, have long vision, make or even change rules, which makes the person can work better. When Spiritual Intelligence is held in the low category will result in a decrease in performance. This is due to spiritual intelligence possessed, a person is able to adapt to the tasks assigned to the nurse. So that the services provided are more optimal and of high quality

\section{Conclussion}

The conclusion in this research is that emotional intelligence has a significant positive effect on job satisfaction. The higher the emotional intelligence, the higher the job satisfaction. Secondly, emotional 
intelligence has a significant positive effect on nurse performance. The higher the emotional intelligence, the higher the nurse's performance. Third, intelligence spiritual significant positive effect on job satisfaction. The higher the spiritual intelligence, the higher the job satisfaction. Fourth, spiritual intelligence significantly positive effect on nurse performance. The higher the spiritual intelligence, the higher the job satisfaction. This shows that emotional intelligence and spiritual intelligence which is owned by a nurse has an important role on job satisfaction and performance of nurses in Buleleng General Hospital.

\section{Reference}

Aditama, T.Y. (2007). Manajemen administrasi rumah sakit. Edisi kedua. Jakarta: UI Press

Agustian, A.G. (2006). Rahasia Sukses Membangkitkan ESQ Power . Jakarta : Penerbit Arga.

Edwardin, L.T.A.S. (2006). Analisis Pengaruh Kompetensi Komunikasi, Kecerdasan Emosional, Dan Budaya Organisasi Terhadap Kinerja Karyawan (Tesis). Universitas Diponogoro.

Ghozali, I. (2008). Structural Equation Modeling Metode Alternatif dengan Partial Least Square Edisi Kedua. Yogyakarta: Badan Penerbit Universitas Diponegoro.

Gillies, Dee Ann. (2000). Manajemen keperawatan, sebagai suatu pendekatan sistem, penerjemah Neng Hati Sawiji, Bandung: Yayasan IAPKP.

Golemen, D. (2000). Emotional Intellegent: Kecerdasan Emosional, Mengapa EI lebih penting dari IQ. Jakarta: Gramedia Pustaka Utama.

Gordon, E, (2004, Desember 12). EQ dan Kesuksesan Kerja. Focus-online. Diakses dari http://www.epsikologi. om,

Handayani, R.I. (2014). Pengaruh Kecerdasan Emosional dan Kecerdasan Spiritual terhadap Karyawan Pada Hotel Ijen View (Tesis). Universitas Jember.

Handoko, T. H. (2003). Manajemen Cetakan 18. Yogyakarta: BPFE Yogyakarta.

Khavari. (2006). Mencapai Kebahagiaan dalam Setiap Keadaan. Jakarta: Mizan Pustaka.

Luthan, F. (2004). Perilaku Organisasi. Yogyakarta: Penerbit Andi.

Moore, W.T., \& Wendy, J.C. (2006). An Examination Of Proxy Measures Of Workplace Spirituality: A Profile Model of Multidimensional Constructs. Journal Of Leadership And Organizational Studies. 1294),109.https://www.researchgate.net/publication/250961767_An_Examination_of_Proxy_Mea sures_of_Workplace_Spirituality_A_Profile_Model_of_Multidimensional_Constructs.

Sukmawati \& Gani,N. (2014). Pengaruh Kecerdasan Emosional, Kepuasan Kerja, Dan Komitmen Organisasi Terhadap Kinerja Karyawan Pada Koperasi Karyawan Pt. Telkom Siporennu Makassar. Jurnal Manajemen Akuntansi. 3(3),27. http://publishing-widyagama.ac.id/ejournalv2/index.php/ima/article/view/233.

Sunandar,M.A. (2018). Kecerdasan Spritual dan Motivasi Terhadap Kepuasan Kerja Serta Kinerja Perawat Pelaksana di Rawat Inap Rumah Sakit Islam Jakarta Cempaka Putih. Indonesia Jurnal Of Nursing Sience dan Partice.1(1), 53. https://jurnal.umj.ac.id/index.php/ijnsp/article/view/2704.

Supriyatno, A. S., \& Ibrahim, M. M. (2018). Pengaruh Kecerdasan Emosional dan Kecerdasan Spiritual terhadap Kepemimpinan Transformasional, Kepuasan Kerja dan Kinerja Manajer (Studi di Bank Syari'ah Kota Malang). Jurnal Aplikasi Manajemen. Vol.10 No. 4. 698-699. https://jurnaljam.ub.ac.id/index.php/jam/article/view/455,

Thomas, Sy, S. T., and Linda, A.O. (2006). Relation of Employee and Manager Emotional Intelligence To Job Satisfaction And Performance. Journal of Vocational Behaviour . 68, p.461-473. 
https://www.researchgate.net/publication/222929783 Relation of employee and manager emoti onal intelligence to job satisfaction and performance.

Trihandini, R.A.F.M, (2005). Analisis Pengaruh Kecerdasan Intelektual, Kecerdasan, dan Kecerdasan Spiritual Terhadap Kinerja (Studi Kasus Pada Hotel Horison Semarang).Tesis. Megister Manajemen Universitas Diponegoro.

Zohar, D., dan Marshall, I .(2007). SQ: Spiri- tual Intelligence The Ultimate Intelli- gence. Bandung: Penerbit Mizan Media Utama 